UDC: 372.881 .111 .1

DOI: https://doi.org/10.24195/2414-4665-2017-5-25

Iryna Lobachova,

PhD (Candidate of Philological Sciences), associate professor, Department of Primary Education Theory and Practice

Donbas State Pedagogical University,

12, Universytetska Str., Sloviansk, Ukraine

\title{
THE PRACTICAL VALUE OF USING WIMMELBUCH IN TEACHING ENGLISH TO PRIMARY SCHOOLCHILDREN
}

The paper deals with the relevant issue of primary education - researching the optimization of the educational process at foreign language lessons through the implementation of the Wimmelbuch for the formation of foreign language communication skills of primary schoolchildren. The Wimmelbuch method is based on the communicative approach to teaching foreign languages. The main role of using the Wimmelbuch is forming students' needs in speaking, which is provided by its main feature: students try to resolve the real and imaginary problems. The work with the Wimmelbuch in teaching English fulfils educational, motivational, orientational, compensative, and educating functions that optimizes the educational process. According to the results of carried out experiment the positive dynamics in mastering and reproducing the foreign language material has been noted in the experimental subgroup. Thus, the use of the Wimmelbuch at the English language at primary school can increase the level of schoolchildren's communication skills.

Keywords: Wimmelbuch, visual teaching means, foreign language communication skills, oral speech, primary schoolchildren, functions of the Wimmelbuch.

\section{Introduction}

Integration of Ukraine into the European economic field requires from a conscious citizen of Ukraine to master foreign languages, that creates the preconditions for the personal, cultural and professional individual's development. Thus, in the normative and legal documents (the Law of Ukraine "On Education" (1991), "On General Secondary Education" (1999), National Doctrine of Education Development (2002), the State Standard of Full Secondary Education (2004), the Concept of Special Education (2003), "The West-European Recommendations on Language Education..." (2003) it is stated that since 2012 English has been taught starting from the first grade [1]. So, the issue of teaching a foreign language as a means of intercultural communication is considered to be relevant and requires new approaches to the educational process at English lessons at primary school, improving traditional methods and using innovative ones.

In the scientific sphere, the issue of training prospective teachers of foreign languages is interpreted by such modern researchers as O. Beskorsa, O. Bigych, L. Byrkun, I. Vereshchagina, O. Ishutina, I. Mamchur and others. The way of improving the study of foreign languages at primary school is considered by M. Denysenko, O. Kolominova, S. Nikolaieva, V. Plakhotnyk and others. The research of the specifics of communicative phenomena is carried out by such scholars as M. Bovtenko, O. Bigych, L. Byrkun, I. Hrechykhin, V. Demiankov, Yu. Karaulov and others. The lack of the complex analysis of the issue of implementing such visual teaching means as a Wimmelbuch at English lessons at primary school in the theoretical and practical plane determines the relevance of its studying. The aim of the article is provide a theoretical and methodological basis of the issue of using the Wimmelbuch at English lessons at primary school for the formation of communication skills of primary schoolchildren. The outlined aim involves the following objectives: 1) considering the theoretical aspect of implementing the Wimmelbuch at English lessons at primary school; 2) outlining the main statements of using the Wimmelbuch in studying English; 3) defining the functions of the Wimmelbuch at English lessons at primary school.

\section{Research methods}

The main purpose of teaching a foreign language is the formation of foreign language communication skills. Thus, the experimental research, that was held in 20162017 at Serhiivska comprehensive school of Sloviansk district council of Donetsk region in the 2-A form, was aimed to check the hypotheses: forming foreign language communication skills of primary schoolchildren will be successful due to implementing visual teaching means such as the Wimmelbuch into the educational process.

By means of the confirmatory experiment some common challenges that needed certain correction have been determined: students' low activity in learning English; lack of personal interest in in successful learning of English; inefficiency in memorizing a new foreign language vocabulary that leads to the failure of realizing an act of communication; the lack of positive attitude to learning English during the lessons, etc.

We believe that these problems are caused by the use of the traditional approach to learning a foreign language due to the following negative aspects: teaching is only transferring the ready knowledge; focusing on an ordinary 
student when presenting the learning material and throughout the whole educational process; individual and psychological features of schoolchildren are ignored; high load upon students' memory and so on. Therefore, it is necessary to search for the ways to improve the efficiency of teaching a foreign language by introducing new methods focusing on student-centered approach.

According to the results of the assessment of the students' educational achievements the group was divided into two subgroups. The confirmatory experiment has made it possible to assess the schoolchildren's level of English communication skills in the following way:

$-1^{\text {st }}$ subgroup: a) high level -1 student $(13 \%)$; b) sufficient level -3 students $(37 \%)$; c) medium level -3 students (37\%); d) low level - 1 student (13\%).

$-2^{\text {nd }}$ subgroup: a) high level $-0(0 \%)$; b) sufficient level - 6 students $(74 \%)$; c) medium level - 1 student (13\%); d) low level - 1 student (13\%).

The levels were assessed according to the following characteristics:

1. High level: a student can build a monological utterance and dialogue interaction logically as needed, using grammatical structures and lexical units in accordance with the communicative task, avoiding phonemic mistakes.

2. Sufficient level: a student can speak logically and coherently within a certain topic in accordance with the educational situation and the content of the material read, heard or seen, expressing his/her attitude to the subject of talk. A student can keep up a conversation using simple sentences.

3. Medium level: a student can build a small monologue statement and dialogue interaction logically using a limited vocabulary and elementary grammatical structures, making few mistakes when using lexical units. All sounds are spoken correctly.

4. Low level: a student knows the most commonly learned word combinations, but does not always use them correctly in speech. A student has difficulties in solving the communicative task of a given topic and makes phonemic mistakes.

The obtained results show that the level of the formation of students' communication skills of the $2^{\text {nd }}$ subgroup is a little bit lower than in the $1^{\text {st }}$ one (that is why the $2^{\text {nd }}$ subgroup is an experimental one and the $1^{\text {st }}$ subgroup is the control one).

The results of the assessment have shown that most of the students have the sufficient level of foreign language communication skills so they should be developed to be increased to the high one. We believe that these are the innovative technologies and active teaching methods which can help students to enrich their knowledge and develop their communication skills. In our research, we are focused on the visual method called "Wimmelbuch", aimed at the formation elementary foreign language communication skills and qualities necessary for mastering the minimized scope of knowledge and skills at primary school in accordance with the syllabus.
The control subgroup was taught according to the traditional methods, while in the experimental one we used the Wimmelbuch as a way of developing their English communication skills.

The reassessment of the students' knowledge after conduction the experiment was carried out in both the control and experimental subgroups. It has resulted in the following outcomes:

$-1^{\text {st }}$ subgroup: a) high level -1 student (13\%); b) sufficient level -3 students (37\%); c) medium level - 3 students (37\%); d) low level -1 student (13\%).

$-2^{\text {nd }}$ subgroup: a) high level $-2(26 \%)$; b) sufficient level - 5 students $(61 \%)$; c) medium level - 1 student $(13 \%)$; d) low level - $0(0 \%)$.

Thus, the data analysis shows that in the experimental subgroup more positive results were obtained, which means that comparing to the students from the control one, these children's communication skills were much more developed. It confirms the hypothesis about the effectiveness of using the Wimmelbuch for the development of communication skills of primary schoolchildren at English lessons. The obtained theoretical and practical conclusions show that the determined and theoretically grounded pedagogical conditions of using the Wimmelbuch promote the development of communication skills of primary schoolchildren.

\section{Discussion}

In the curricula for comprehensive schools it is determined that students have to master foreign language material for correct using it in speech situations, to be able to choose independently the appropriate language and speech means adequate to the intention of the speaker and the communicative situation. So, students have to acquire foreign language communication skills to use them in real communication situations.

Implementing the work with the Wimmelbuch at lessons makes it possible to activate the process of learning English by catching the schoolchildren's interest. The Wimmelbuch is the visual means belonging to the group of active methods of teaching practical English. It is an activity picture book with bright and vivid illustrations, a great number of details, characters which are easy to recognize, and with the almost absence of a text. The Wimmelbuch is also called a living book, because it is about life: there are lots of swarming characters and events [1].

Plot pictures of Wimmelbuch are the conditional reproduction of the real practical activities of people, so they create conditions for real communication. The effectiveness of learning here is primarily explained by the explosion of motivation, increase the personal interest in learning English.

Such a book motivates students to speak because they find themselves in a situation where the need to say something, ask, find out, prove, etc. is actualized. Schoolchildren are clearly convinced that the language can be used as a means of communication. It activates children's desire to contact with each other and a teacher, 
creates conditions for equality in the language partnership, destroys the language barrier. Being in the created situations students learn the following elements of communication: the ability to begin a conversation, keep it, interrupt an interlocutor, agree or disagree with his/her opinion at the right moment; the ability to listen to an interlocutor consciously, ask clarifying questions, etc. [2].

Such activity involves the participants into the process of practicing the language because both a speaker and a listener are as active as possible, as they have to understand and memorize the replica of a partner, to correlate it with the situation, to determine how it is relevant to the situation and the task of communication, and to react properly.

For example, at the beginning of the book "Day at the Zoo" there is an instruction how to use it and tasks for the search strategy. In addition, at each page there is the zoo at the different time of a day. The activity of the participants, workers and visitors of the zoo (or their absence) is determined by the time of a day. There is the task at each page - to find a character or a thing, and also one should also remember about the main task that is given at the beginning of the book. Here we can see that a day at the zoo starts early in the morning when it is still dark, with feeding the animals and cleaning up; kiosks are opened; visitors are coming; an elephant is brought; a monkey has run away; a thunderstorm has begun and all visitors are running away; the zoo is closed in the evening, the animals have a rest, etc. It is also interesting to observe the caretaker's work at the zoo, cute monkeysgibbons, a pickpocket, etc. Thus, the book prompts to search for and find secrets, making participants involved in the process of searching for something new among the great number of small figures and elements of the picture [3].

In addition, the work of the Wimmelbuch helps to uncover the reserve possibilities of primary schoolchildren to memorize a significant amount of educational material.

The communicative approach to teaching foreign languages is the basis of the work with the Wimmelbuch. It is not just creating conditions in which students are

\section{REFERENCES}

1. Lobachova, I. (2017). Pedagogical Conditions of Using a Wimmelbuch at English Lessons at Primary School. Profesionalizm pedahoha : teoretychni $y$ metodychni aspekty - Professionalism of the teacher: theoretical and methodical aspects, 5 (2): [naukove elektronne vydannia]. Retrieved from http://pptma.dn.ua/index.php/uk/ [in English].

\section{ЛIТЕРАТУРА}

1. Lobachova I. Pedagogical Conditions of Using a Wimmelbuch at English Lessons at Primary School / Lobachova I. // Професіоналізм педагога : теоретичні й методичні аспекти : [наукове електронне видання]. - suggested to act but it is direct motive for activity under certain conditions. Students do not "memorize and act" that is typical for the conditional and communicative approach, but they "memorize when acting". The main role of the Wimmelbuch in teaching foreign languages is the formation of students' needs in speech activity.

The work with the Wimmelbuch in teaching English fulfils the following functions: 1) educational (the use of the Wimmelbuch is a special exercise, its purpose is to master skills and abilities of both monologue and dialogical speech in interpersonal communication); 2) motivational (due to using the Wimmelbuch the mechanisms of motivation are activated; the pictures of the Wimmelbuch as a model of interpersonal communication contribute to this, stimulating students' interest in foreign language communication); 3) orientational (the illustrative material of the Wimmelbuch helps children to plan their own speech behavior and predict the behavior of an interlocutor, develops the ability to evaluate actions); 4) compensative (the tasks for the pictures of the Wimmelbuch which are selected methodically and correctly allow to resolve the contradictions which arise between the student's need to perform a speech act and the inability to perform operations required by the action); 5) educating (the all-round impact on students is provided due to a number of tasks for the pictures of the Wimmelbuch), etc.

\section{Conclusions}

It has been proved that the implementation of the Wimmelbuch into the educational process has a positive impact on the formation of primary schoolchildren's cognitive interests, the development of foreign language communication skills, and promotes the conscious learning of English. It also helps to develop such personal qualities as independence, initiativeness, tolerance, empathy, etc. Primary schoolchildren study actively, work with pleasure, help each other, listen to their classmates attentively; and a teacher only controls the educational activity.

Our further research studies are planned to be dedicated to the analysis of exercises for the effective work with the Wimmelbuch at the English lessons.

2. Ganz schön bunt, das alte Wolfratshausen [It was quite colorful, the old Wolfratshausen]. Retrieved from: http://www.sueddeutsche.de/muenchen/wolfratshausen/wi mmelbuch-ganz-schoen-bunt-das-alte-wolfratshausen1.3254720 [in German].

3. Wimmelbuch Club. Retrieved from: http://wimmelbuch.club/ [in Russian].

Вип. 5. - Ч.2. - 2017. - Режим доступу : http://pptma.dn.ua/index.php/uk/

2. Ganz schön bunt, das alte Wolfratshausen [Електронний ресурс]. - Режим доступу : http://www.sueddeutsche.de/muenchen/wolfratshausen/wi 
mmelbuch-ganz-schoen-bunt-das-alte-wolfratshausen1.3254720
3. Wimmelbuch Club [Електронний pecypc]. - Peжим доступу : http://wimmelbuch.club/

\section{Ірина Миколаӥвна Лобачова, кандидат філологічних наук, доцент кафедри теорії і практики початкової освіти, Донбаський державний педагогічний університет, вул. Університетська 12, м. Слов'янськ, Україна}

\section{ПРАКТИЧНА ЗНАЧУЩІСТЬ ЗАСТОСУВАННЯ ВІММЕЛЬБУХІВ ПІД ЧАС НАВЧАННЯ АНГЛІЙСЬКОЇ МОВИ УЧНІВ МОЛОДШОГО ШКІЛЬНОГО ВІКУ}

Статтю присвячено актуальній проблемі початкової освіти - дослідженню оптимізації навчальновиховного процесу на уроках іноземної мови завдяки імплементації віммельбухів для формування іншомовних комунікативних умінь учнів молодшого шкільного віку на початковому ступені вивчення англійської мови. Ураховуючи специфіку поставлених завдань, у науковому дослідженні використано такі методи, як порівняння, узагальнення; педагогічний експеримент, спостереження, метод вивчення продуктів діяльності респондентів, тестування, що дозволило проникнути в сутність окресленої проблеми, логічно перейти від загальної думки до конкретної. У статті доведено, що в основу роботи з віммельбух покладено комунікативний підхід до навчання іноземних мов: не просто створення умов, у яких пропонується діяти учням, а безпосередньо спонукання до діяльності у запропонованих умовах. 3'ясовано, що засвоєння іноземної мови відбувається насамперед у ії комунікативній функції, тобто в процесі діяльності з позамовною метою. Пріоритетна роль при навчанні іноземних мов завдяки віммельбух відводиться формуванню потреби учнів у мовленнєвих діях, бо навчання має діяльнісний характер: учні намагаються вирішити реальні та уявні завдання. Робота з таким засобом наочності як віммельбух у навчанні англійської мови консолідує такі функції, як навчальну, мотиваційно-збуджувальну, орієнтувальну, компенсаторну, виховну, що оптимізує навчально-виховний процес на уроці англійської мови в початковій школі. За результатами проведеного контрольного етапу експерименту в експериментальній підгрупі зафіксовано позитивну динаміку в засвоєнні та відтворенні іншомовного матеріалу: приріст склав $13 \%$. У статті визначено головні положення використання віммельбухів на уроках англійської мови: створення сприятливих умов для оволодіння усним мовленням; забезпечення особистісно орієнтованого навчання; створення емоційно-позитивних стосунків між учителем та учнями; акцентування на усномовленнєвій комунікації.

Ключові слова: віммельбух, наочні засоби навчання, іншомовні комунікативні вміння, усне мовлення, учні початкової школи, функції віммельбух.

Doctor of Pedagogy, prof. L. Havrylova 